Peace vision and its socio-emotional antecedents:

The role of forgiveness, trust and inclusive victim perceptions

\author{
Masi Noor ${ }^{1}$ \\ Nurit Shnabel $^{2}$ \\ Samer Halabi ${ }^{3}$ \\ Bertjan Doosje $^{4}$
}

${ }^{1}$ Liverpool John Moores University, ${ }^{2}$ Tel Aviv University, ${ }^{3}$ Tel Aviv Yaffo Academic College, ${ }^{4}$ University of Amsterdam

For correspondence, please contact Masi Noor, Liverpool John Moores University, Liverpool, L3 3AF, United Kingdom; email: a.m.noor@ljmu.ac.uk or masi.noor1@gmail.com

The first and second authors contributed equally to this manuscript. The order of their names is in alphabetical order. 


\begin{abstract}
The present study conceptualized peace vision as the view of peace as desirable, feasible and requiring substantial concessions by both parties and examined the social-emotional factors contributing to its endorsement among Israeli Jews $(N=$ 400). In line with our theorizing, we found that trust in Palestinians and inclusive victim perceptions (the view that both conflicting groups have suffered due to the conflict) were significantly and positively associated with peace vision endorsement both directly and indirectly, through facilitating forgiveness. We discuss the theoretical and practical implications of these results in terms of the sustainability of peaceful co-existence between conflicting groups.
\end{abstract}




\section{Peace vision and its socio-emotional antecedents: \\ The role of forgiveness, trust and inclusive victim perceptions}

In order to carry a positive action we must develop here a positive vision.

Dalai Lama

Groups involved in prolonged, violent, seemingly intractable conflicts sometimes reach a point where they may be willing to end the conflict, for example, due to conflict fatigue (Kelman, 2004). However, just as removing weeds is not enough to make a garden flourish, the wish to end the conflict is not enough to bring about peace, as it must be founded on a clear vision regarding the nature of this peace (see Pittinsky, 2012, for similar reasoning). In particular, we argue that such peace vision requires group members to realize that peace is desirable (i.e., serves their ingroup's interest), feasible (despite deep-rooted intergroup rivalry), and necessitates substantial concessions by both parties (such that both, and not just the outgroup, are responsible for its success or failure). The goal of the present research is to elucidate the concept of peace vision, comprised of these three related beliefs, and point to socio-emotional factors contributing to its endorsement.

The first belief comprising peace vision regards its desirability: conflicting groups may not necessarily view peace as a desirable goal that best serves their ingroup's interests. For example, they may perceive the overall costs involved in maintaining the conflict (e.g., casualties and damage to property) as lower than the costs involved in reaching peace (e.g., giving up territory and control over sacred places) (Bar-Tal, Halperin, \& Oren, 2010). This perception may be particularly pronounced when group members believe that their present position will improve in 
the future, enabling them to eventually win the conflict and avoid the costs of peace (Halperin \& Bar-Tal, 2011). A peace vision thus requires group members to realize that despite its inevitable costs, the cessation of conflict is in their best interest (Gayer, Landman, Halperin, \& Bar-Tal, 2009). Such a realization is reflected in Israel's former Prime Minister Menachem Begin's statement, when signing the then controversial peace agreement with Egypt, that "[t]he hardships of peace are better than the pain of war."The second belief comprising peace vision regards its feasibility: even if group members do believe that peace is in their best interest, they may still think that it is not feasible because there is "no partner" (Halperin \& Bar-Tal, 2007, p. 5). Namely, peace cannot be achieved because the other conflict party is unwilling to end the cycle of violence and reach a compromise. In fact, the societal belief that the ingroup genuinely wishes peaceful coexistence whereas the outgroup wants war and bloodshed has been identified by Bar-Tal (2007) as one of the key themes in the ethos of conflict (i.e., shared societal beliefs that constitute the narrative about the conflict's nature). This belief fuels the conflict because it helps group members maintain their ingroup's positive image as just and moral regardless of its aggressive acts (Bar-Tal, 2000). Hence, a peace vision must include not only the belief that peace is desirable but also the belief that it is viable; that is, peace must not be viewed as a vague and romantic future option, but rather as a concrete possibility (see Bar-Tal, 2000; 2007).

Finally, the third belief is concerned with group members' realization that both groups must make substantial compromise in order to achieve peace. In particular, group members may find it extremely difficult to make the concessions required for reaching peace. According to Rouhana (2004), peace and reconciliation entail various risks in terms of "threats to national identity and national narrative, political 
restructuring, and permanent political loss" (p. 40). To illustrate, reaching a peaceful solution may require groups to accept collective guilt for their wrongdoing, which runs counter to their members' wish to preserve a positive, moral social identity (Wohl, Branscombe, \& Klar, 2006), as well as to relinquish core religious and national aspirations (Bar-Tal et al., 2010). Thus, even group members who view peace as desirable and feasible often "talk the talk" without "walking the walk" of supporting substantial compromise; this may be particularly true of members of the more powerful group, for whom the risks and costs of peace (e.g., loss of dominance) are higher than those of the less powerful group (Rouhana, 2004). Hence, in addition to desirability and feasibility, a peace vision must refer to the means through which peace can actually be achieved - it must articulate the realization that peace requires a cut-to-the-bone compromise on both sides.

Note that while we acknowledge that these three beliefs are different from each other, we nevertheless argue that they should be considered together, as all are critical elements of peace vision. Endorsing one or two of these beliefs without the third implies lack of genuine commitment to achieving peace. In fact, as illustrated in our discussion of the feasibility dimension above, such partial endorsement often serves as a barrier to peace.

\section{The role of forgiveness in promoting peace vision}

Whereas previous research has focused on the role of "cold" cognitive factors such as cost-benefit calculations (Gayer et al., 2009) in promoting the endorsement of peace vision, the present research focuses on a "warm," socio-emotional factor of intergroup forgiveness. Specifically, we examined the association between forgiveness and the endorsement of peace vision among Israeli Jews. 
Building on McCullough et al.'s (1998) theorizing, we suggest that a group can respond to its victimization by another through retaliation (e.g., militant actions), disengagement (e.g., building a separation wall), or forgiveness, namely, engagement in constructive efforts to restore the fractured relationship between the groups, while letting go of past grudges. Over the last decade, a growing body of social psychological research has explored intergroup forgiveness as a means for shifting the focus of intergroup relations from the painful past to a positive future (Hewstone et al., 2004; Hewstone, Cairns, Voci, Hamberger, \& Niens, 2006; Noor, Brown, Gonzalez, Manzi, \& Lewis, 2008; Noor, Brown, \& Prentice, 2008; Noor, Brown, Taggart, Fernandez, \& Coen, 2010; Wohl \& Branscombe, 2005).

Admittedly, some researchers have warned of potential negative consequences of forgiveness, such as providing impunity to the perpetrating group (Staub, Pearlman, Gubin, \& Hagengimana, 2005) and reducing the victim group's motivation to act for social change (Greenaway, Quinn, \& Louis, 2011). Nevertheless, forgiveness has also been repeatedly observed as contributing to various positive intergroup outcomes. To illustrate, across correlational and longitudinal data-sets Noor, Brown, Gonzalez and colleagues (2008) found that forgiveness was a robust and positive correlate of reconciliation attitudes among Protestants and Catholics in Northern Ireland. Similarly, Čehajic, Brown, and Castano (2008) found that forgiveness for misdeeds during the war in Bosnia and Herzegovina was positively associated with Bosnian Muslims' reduced wish to distance themselves from Bosnian Serbs, and Wohl and Branscombe (2005) reached similar conclusions in the context of contemporary relations between North American Jews and Germans. Thus, along with theorizing regarding its evolutionary advantages (McCullough, 2008) and therapeutic value (Enright \& Fitzgibbons, 2000), forgiveness seems to serve, at least 
under certain circumstances, as a socio-emotional route for repairing damaged intergroup relations.

Based on this logic, we theorized that by transforming an ingroup's psychological orientation towards the adversarial outgroup (Staub, 2008), forgiveness can enable groups to envisage peaceful coexistence as a desirable and feasible outcome that is worth compromising for. That is, we hypothesized that forgiveness attitudes would be positively associated with the endorsement of peace vision (H1). Trust and inclusive victim perceptions as antecedents of forgiveness and peace vision

Previous research (for a meta-analysis, see Van Tongeren, Burnette, O’Boyle, Worthington, \& Forsyth, 2014) has identified several antecedents of intergroup forgiveness, including empathy (e.g., perspective taking) and intergroup contact (e.g., Hewstone et al., 2006); reduced anger and infra-humanization (e.g., Tam et al., 2007); and collective guilt (e.g., Hewstone et al., 2004). The present study focuses on two other key antecedents identified in the literature: intergroup trust (Hewstone et al., 2006) and inclusive perceptions of victimhood (acknowledging that both sides have experienced victimization, Vollhardt, 2009; 2012; 2013), shown in previous research to affect Israeli Jews' forgiveness tendencies (Nadler \& Liviatan, 2006, and Shnabel, Halabi, \& Noor, 2013, respectively). We aimed to replicate and extend these findings by testing the role of trust and inclusive victim perceptions in promoting forgiveness as well as consequent peace vision endorsement.

Trust. Theorizing on revenge and forgiveness suggests that the decision to forgive one's adversary depends on "estimating the risk of future exploitation by the harmdoer and the expected future value of the relationship with the harmdoer" (McCullough, Kurzban, \& Tabak, 2013, p. 1). That is, people will choose this strategy 
only if they believe that they can benefit from restoring positive relations with the other-conflict party, and that their willingness to show benevolence despite the transgression will not lead to further exploitation by the transgressor. Otherwise, imposing retaliatory costs on their aggressors in order to create deterrence constitutes a better strategy to prevent future transgressions (McCullough, et al., 2013; see also Burnette, McCullough, Van Tongeren \& Davis, 2012). The prediction derived from this theorizing is that trust - the belief the perpetrator group now has positive intentions towards the ingroup and that despite the painful past it is possible to establish cooperative, mutually beneficial relations with it (see Carnevale, 1995) - is a prerequisite for forgiveness (Hewstone et al., 2008). In the absence of trust, even conciliatory gestures by the perpetrator group are likely to be interpreted as manipulative ploys. To illustrate, Nadler and Liviatan (2006) found that among Israeli Jews with a low level of trust in Palestinians, exposure to an empathic message from a Palestinian representative backfired, leading to lower levels of willingness to forgive and reconcile with Palestinians.

While Nadler and Liviatan (2006) did not directly examine the association between trust and forgiveness, their findings imply that, consistent with evidence obtained in other contexts of intergroup conflict (e.g., Noor, Brown, Gonzalez et al., 2008; Hewstone et al., 2006), higher levels of trust in Palestinians should be associated with greater forgiveness tendencies among Israeli Jews (H2). As for the relation with peace vision endorsement, we expected higher levels of trust to be associated with greater endorsement of peace vision both directly (H3), because trust is crucial for the belief that peace is feasible as well as for the readiness to make risky concessions, and indirectly, through the promotion of forgiveness (H4). 
Inclusive victim perceptions. The relations between Palestinians and Jews are characterized by significant power asymmetry, as Jews have greater military, economical, and political strength (Aggestam, 2002). Nevertheless, through the course of the conflict, both parties have transgressed against each other and hence served as victims in some situations and as perpetrators in others (Siman ToveNachlieli \& Shanbel, 2014). In such contexts of mutual transgressions, members of both groups are strongly motivated to establish their own victimhood status, while dismissing the suffering of the outgroup (Noor, Shnabel, Halabi, \& Nadler, 2012). Because the motivation to receive acknowledgement for the ingroup's suffering is inconsistent with letting go of the past, groups' engagement in such competitive victimhood is associated with reduced forgiveness, as found across various contexts (e.g., Noor, Brown, Gonzalez et al., 2008). By contrast, inclusive victim perceptions, that is, the belief that both groups have been victimized in the conflict, have been found to be associated with greater forgiveness (Vollhardt, 2009; 2012; see also Bilali \& Vollhardt, 2014). Indeed, the notion that inclusive victim perceptions may lead to mutual forgiveness was one of the rationales behind the Truth and Reconciliation Commissions in post-apartheid South Africa (Tutu, 1999; see Rimé, Kanyangara, Yzerbyt, \& Paez, 2011, for the Gacaca tribunals in Rwanda).

Of direct relevance to the present research, inducing a common victim identity among Israeli Jews and Palestinians (i.e., "both Palestinians and Jews are victims of the regional conflict") was found to lead to heightened levels of mutual forgiveness (Shnabel et al., 2013). While Shnabel et al. (2013) used an experimental manipulation to test the relations between the two variables, their findings imply that even when examining the naturally occurring correlation, more inclusive victim perceptions should be associated with greater forgiveness tendencies among Israeli Jews (H5). As 
for the relation with peace vision endorsement, we expected more inclusive victim perceptions to be positively associated with greater endorsement of peace vision directly (H6), because they may foster belief in the viability of peace - as the other conflict party is no longer viewed exclusively as an irrational, evil aggressor - and lead to greater appreciation of the pain and loss involved in the continuation of the conflict (see Gayer et al., 2009). In addition, we expected inclusive victim perceptions to contribute to peace vision indirectly, through the promotion of forgiveness $(\mathrm{H} 7)$.

\section{Method}

\section{Respondents}

Four hundred participants from the general Jewish population were surveyed in Israel in July 2012. Participants' age range was: $16.5 \%=18-24 y r s ; 21 \%=25$ $34 \mathrm{yrs} ; 17 \%=35-44 \mathrm{yrs} ; 16 \%=45-54 \mathrm{yrs} ; 13 \%=55-64 \mathrm{yrs} ; 16.5=65+\mathrm{yrs}$. About half of the sample (48\%) consisted of men and the rest (52\%) were women. In terms of residency, about half of the participants (51\%) were from Tel-Aviv metropolitan area, $24 \%$ from Haifa and the north, $13 \%$ from Beersheba and the south, and 12\% from Jerusalem and the West Bank. In terms of stated political orientation, 22\% were leftists, $31 \%$ centrists, and $47 \%$ were rightists. The majority (72\%) were born in Israel, and the rest in the former Soviet Union (11\%) and various other countries (17\%). The majority of participants were married with $(53.5 \%)$ or without (7.5\%) children, $26 \%$ were single, $12 \%$ divorced, and $1 \%$ had a different marital status. Most participants (66\%) were secular, $19 \%$ were traditional, and $15 \%$ orthodox. About half (51\%) had an academic degree. Finally, $30 \%$ of the participants reported an average income, $33.5 \%$ were below average, and $30 \%$ were above average; $6.5 \%$ refused to report their income.

\section{Procedure and Materials}


The survey company collected data from participants in return for 4 NIS (about 1 USD) to compensate them for their time. The online invitation to participate was sent to all pool members; data collection was stopped after 400 participants completed the survey.

Measures. All measures used a 7-point Likert scale, ranging from 1 (strongly disagree) to 7 (strongly agree). We measured forgiveness with two items (derived from Noor et al., 2008): "My group should forgive the Palestinians for the suffering they have caused us during the conflict"; and "My group should put the past behind it and not hold a grudge against the Palestinians" $(r=.73, p=.001)$. Trust was measured with two items (derived from Nadler \& Liviatan, 2006): "Thinking of Palestinians, do you generally have trust in the good intentions of their leadership?"; and "Do you generally have trust in the good intentions of ordinary Palestinians?" $(r$ $=.55, p=.001)$. Based on Vollhardt's (2009) and Noor and colleagues' (2012) conceptualisation of this construct, two items were developed to tap inclusive victim perceptions: "In one way or another, we, Palestinians and Israelis, are all victims of the regional conflict"; and "The heartache due to losing one's family members to the regional conflict is the same for both Israelis and Palestinians" $(r=.47, p=.001)$. Finally, three novel items measured peace vision: "The costs of continuing the regional conflict are higher than the costs involved in ending it"; "A shared peaceful future between Palestinians and Israelis is possible"; and "Both Israelis and Palestinians have to make significant concessions to end the conflict" $(\alpha=.78)$.

Additionally, participants provided information on a range of variables: highest educational attainment, level of income in comparison to the average national income (1 = Much below average to $7=$ Much above the average $)$, age, gender, religious sector (secular, traditional, or orthodox) and degree of religiosity $(1=$ Very 
secular to $7=$ Very religious), residence, place of birth, marital status, and political orientation $(1=$ leftist to 7 = rightist $)$.

\section{Results}

Table 1 provides a summary of correlations, means and standard deviations of all measured variables. To test our hypotheses, we used the MEDIATE macro developed by Hayes and Preacher (2013). This macro enabled us to simultaneously test the direct and the indirect effects, mediated through forgiveness, of trust and inclusive victim perceptions on peace vision endorsement. Moreover, it allowed us to control for all the relevant demographic variables (e.g., political orientation) and thus isolate the unique contribution of the socio-emotional factors which were the focus of our inquiry. In particular, the MEDIATE macro computed two regression models, followed by two bootstrapping analyses of mediation to test for the indirect effects. The upper section of Table 2 presents the first regression model, in which forgiveness was the criterion variable and trust, inclusive victim perceptions, and the demographic variables were the predictors. The obtained model was significant, $F(8,391)=46.00$, $\mathrm{R}^{2}=.48, p<.001$. As seen in the table, in line with $\mathrm{H} 2$ and H5 (respectively), both trust and inclusive victim perceptions were significantly and positively associated with forgiveness. In addition, political orientation (i.e., being a rightist), religiosity, and gender (i.e., being a woman) were negatively associated with forgiveness; whereas age positively correlated with it (income and education were not associated with forgiveness).

The middle section of Table 2 presents the second regression model, in which peace vision endorsement was the criterion variable, and the predictors were forgiveness, trust, inclusive victim perceptions, and the demographic variables. The obtained model was significant, $F(9,390)=60.37, \mathrm{R}^{2}=.58, p<.001$. As seen in the 
table, consistent with H1, H3 and H6 (respectively), forgiveness, trust and inclusive victim perceptions were significantly and positively associated with peace vision endorsement. In addition, political orientation (i.e., being a rightist) was negatively associated with the endorsement of peace vision, whereas age positively correlated with it (religiosity had a marginal negative association, income had a marginally positive association, and education and gender were not associated with peace vision endorsement).

In line with $\mathrm{H} 4$, the first bootstrapping analysis (5,000 resamples) revealed that the indirect effect of trust on peace vision endorsement through forgiveness was significant, $[B=.083, S E=.025,95 \% \mathrm{CI}(.039, .137)]$. In line with $\mathrm{H} 7$, the second bootstrapping analysis (5,000 resamples) revealed that the indirect effect of inclusive victim perceptions on peace vision endorsement through forgiveness was also significant; $[B=.069, S E=.019,95 \%$ CI $(.035, .108)]$.

\section{Discussion}

Peace is much more than merely the absence of war (Christie, Tint, Wagner, \& Winter, 2008). It needs to be envisaged and sustained jointly by conflicting groups. In the present work, we first defined peace vision as a combination of three beliefs, namely, viewing peace as desirable, feasible and requiring substantial concessions by both parties. We then tested whether the endorsement of such a vision among Israeli Jews was associated with a set of socio-emotional factors. The results suggest that trust and inclusive victim perceptions were positively associated with peace vision both directly and indirectly, by facilitating forgiveness.

To the best of our knowledge, this is the first study to examine the relations between these factors in the Israeli-Palestinian context. Our results replicate previous findings regarding the role of trust in promoting forgiveness (e.g., Hewstone et al., 
2006) and the ability of inclusive victim perceptions to promote positive intergroup attitudes (e.g., Vollhardt \& Bilali, 2014) in other context. Successful replications of this nature should not be taken for granted given the challenge of large contextual and significant cultural differences; for example, the present study was conducted in a context of an ongoing conflict, whereas other studies (e.g., Noor et al., 2008) were conducted in contexts of post-violent conflicts such as Northern Ireland and postPinochet Chile.

Extending previous work on the Israeli-Palestinian conflict, we also found that trust, inclusive victim perceptions, and forgiveness were positively associated with peace vision endorsement. Thus, while previous research on the Israeli-Palestinian conflict focused on cognitive factors affecting peace vision (Gayer et al., 2009), the present study established the critical role of socio-emotional factors, the "missing piece" that may be critical particularly in intractable conflicts of this kind. From a broader theoretical perspective, our study took an initial step in pointing to the potential psychological consequences of forgiveness. Notably, the association between forgiveness and peace vision, as well as between the latter and the other socio-emotional factors, were robust and remained significant even when potentially influential demographic variables - including age and political orientation (which significantly correlated with both forgiveness and peace vision endorsement) - were taken into account.

\section{Limitations and future directions}

We tested our hypotheses using cross-sectional data; to establish causality, future research should also use longitudinal and experimental designs. Secondly, although previous work found similar patterns among both Jews and Palestinians (e.g., with regards to the effect of inducing a common victim identity on forgiveness; 
Shnabel et al., 2013), we acknowledge that future research should directly examine the generalizability of our findings to the Palestinian population, as well as in other contexts of intergroup conflict. Thirdly, it could be argued that due to the mode of data collection (i.e., online, "first comes first participates" invitations) the observed results may have been obtained from a biased, self-selected sample (e.g., those who are especially interested in the topic). While we acknowledge that a degree of selfselection may have occurred, the demographics of the present sample, such as gender, age, and distribution of places of residence, were fairly representative of the Israeli Jewish adult population from 2011 (Central Bureau of Statistics, 2011). Finally, online data collection has been found to be effective when studying socially sensitive issues, as in the present study, by virtue of ensuring anonymity and a sense of social disinhibition (Booth-Kewley, Larson, \& Miyoshi, 2007; Ramo, Hall, \& Prochaska, 2010). Nevertheless, future research may benefit from using other data collection methods, such as face-to-face interviews that consider respondents' unique perspective about the topic.

\section{Conclusion}

In sum, this work highlights the importance of peace vision for sustainable, peaceful co-existence between conflicting groups. Our data, which were obtained from a sample of Israeli Jews with daily experience of the ongoing violent conflict with Palestinians, shed light on the social-emotional factors fostering the endorsement of such vision. These factors, complementing the 'cold' cognitive factors proposed by other researchers (Gayer et al., 2009), offer insights into the possible pathways that practitioners and professionals of peacebuilding can fruitfully pursue in order to educate conflicting groups about the value, costs and benefits of genuine peace in the Middle East and further afield. 


\section{References}

Aggestam, K. (2002). Mediating asymmetrical conflict. Mediterranean Politics, 7, 69-91.

Bar-Tal, D. (2000). Shared beliefs in a Society: Social psychological analysis. London:

SAGE.

Bar-Tal, D. (2001). Why does fear override hope in societies engulfed by intractable conflict, as it does in the Israeli society? Political Psychology, 22, 601-627. doi: $10.1111 / 0162-895 X .00255$

Bar-Tal, D. (2007). Sociopsychological foundations of intractable conflicts. American Behavioral Scientist, 50, 1430-1453. doi: 10.1177/0002764207302462

Bar-Tal, D., Halperin, E., \& Oren, N. (2010). Socio-psychological barriers to peace making: The case of the Israeli Jewish society. Social Issues and Social Policy Review, 4, 63109. doi: doi/10.1111/j.1751-2409

Benziman, Y. (2009). Forgive and not forget: The ethics of forgiveness. Jerusalem: Van Leer.

Booth-Kewley, S., Larson, G. E., \& Miyoshi, D. K. (2007). Social desirability effects on computerized and paper-and-pencil questionnaires. Computers in Human Behavior, 23, 463-477. doi:10.1016/j.chb.2004.10.020

Burnette, J., McCullough, M., Van Tongeren, D., \& Davis. (2012). Forgiveness results from integrating information about relationship value and exploitation risk. Personality and Social Psychology Bulletin, 38, 345-356. doi:10.1177/0146167211424582

Carnevale, D. G. (1995). Trustworthy government leadership and management strategies for building trust and high performance. San Francisco: Jossey-Bass.

Cehajic, S., Brown, R., \& Castano, E. (2008). Forgive and forget? Antecedents and consequences of intergroup forgiveness in Bosnia and Herzegovina. Political Psychology, 29, 351-367. doi:10.1111/j.1467-9221.2008.00634.x

Central Bureau of Statistics. (2011). Statistical abstract of Israel 2011. http://www1.cbs.gov.il/reader/shnatonenew_site.htm. 
Christie, D., Tint, B., Wagner, R., \& Winter, D. (2008). Peace psychology for a peaceful word. American Psychologist, 63, 540-552. doi:10.1037/0003-066x.63.6.540

Enright, R., \& Fitzgibbons, R. (2000). Helping clients forgive: An empirical guide for resolving anger and restoring hope. Washington, DC: American Psychological Association.

Gayer, C. C., Landman, S., Halperin, E., \& Bar-Tal, D. (2009). Overcoming psychological barriers to peaceful conflict resolution: The role of arguments about losses. Journal of Conflict Resolution, 53, 951-975. doi:10.1177/002200270934257

Greenaway, K. H., Quinn, E. A., \& Louis, W. R. (2011). Appealing to common humanity increases forgiveness but reduces collective action among victims of historical atrocities. European Journal of Social Psychology, 41, 569-573. doi:

10.1002/ejsp. 802

Halperin, E., \& Bar-Tal, D. (2007). The fall of the peace camp in Israel: The influence of Prime Minister Ehud Barak on Israeli public opinion: July 2000 - February 2001. Conflict \& Communication Online, 6, 1-18.

Halperin, E., \& Bar-Tal, D. (2011). Socio-psychological barriers to peace making: An empirical examination within the Israeli Jewish Society. Journal of Peace Research, 48, 637-651. doi: 10.1177/0022343311412642

Hayes, A. F., \& Preacher, K. J. (2013). Statistical mediation analysis with a multicategorical independent variable. British Journal of Mathematical \& Statistical Psychology. doi: $10.1111 / \mathrm{bmsp} .12028$

Hewstone, M., Cairns, E., Kenworthy, J., Huges, J., Tausch, N., Voci, A., Von Hecker, U., Tam, T., \& Pinder, C. (2008). Stepping stones to reconciliation in Northern Ireland: Intergroup contact, forgiveness and trust. In A. Nadler, T. E. Malloy, J. D. Fisher (Eds.), The social psychology of intergroup reconciliation. (pp.199-226). Oxford: Oxford University Press. 
Hewstone, M., Cairns, E., Voci, A., Hamberger, J., \& Niens, U. (2006). Intergroup contact, forgiveness, and experience of "The Troubles" in Northern Ireland. Journal of Social Issues, 62, 99-120. doi:10.1111/j.1540-4560.2006.00441.x

Hewstone, M., Cairns, E., Voci, A., McLernon, F., Niens, U., \& Noor, M. (2004). Intergroup forgiveness and guilt in Northern Ireland. In N. Branscombe \& B. Doosje (Eds.), Collective guilt: International Perspectives (pp. 193-215). Cambridge, UK: Cambridge University Press.

Kelman, H. C. (2004). Reconciliation as identity change: A social-psychological perspective. In Y. Bar-Simon-Tov (Ed.), From conflict resolution to reconciliation (pp. 111-124). Oxford: Oxford University Press.

McCullough, M. (2008). Beyond revenge: The evolution of the forgiveness instinct. San Francisco: Jossey-Bass.

McCullough, M.E., Kurzban, R., \& Tabak, B.A. (2013). Cognitive systems for revenge and forgiveness. Behavioral and Brain Sciences, 36, 1-58.

McCullough, M. E., Rachal, K. C., Sandage, S. J., Worthington, E. L., Jr., Brown, S. W., \& Hight, T. L. (1998). Interpersonal forgiving in close relationships: II. Theoretical elaboration and measurement. Journal of Personality and Social Psychology, 75, 1586-1603. doi:10.1037/0022-3514.75.6.1586

Nadler, A., \& Liviatan, I. (2006). Intergroup reconciliation: Effects of adversary's expression of empathy, responsibility, and recipient's trust. Personality and Social Psychology Bulletin, 32, 459-470. doi:10.1177/0146167205276431

Noor, M., Brown, R., Gonzalez, R., Manzi, J., \& Lewis, C. A. (2008). On positive psychological outcomes: What helps groups with a history of conflict to forgive and reconcile with each other? Personality and Social Psychology Bulletin, 34, 819-832. doi: $10.1177 / 0146167208315555$ 
Noor, M., Brown, R. J., \& Prentice, G. (2008). Precursors and mediators of intergroup reconciliation in Northern Ireland: A new model. The British Journal of Social Psychology, 47, 481-495. doi:10.1348/014466607X238751

Noor, M., Brown, R., Taggart, L., Fernandez, A., \& Coen, S. (2010). Intergroup identity perceptions and their implications for intergroup forgiveness. The Irish Journal of Psychology, 31, 151-170. doi:10.1080/03033910.2010.10446332

Noor, M., Shnabel, N., Halabi, S., \& Nadler, A. (2012). When suffering begets suffering: The psychology of competitive victimhood between adversarial groups in violent conflicts. Personality and Social Psychology Review, 16, 351-374. doi: $10.1177 / 1088868312440048$

Pittinsky, T. (2012). Us plus them: Tapping the positive power of difference. Boston: Harvard Business School.

Ramo, D. E., Hall, S. M., \& Prochaska, J. J. (2010). Reaching young adult smokers through the internet: Comparison of three recruitment mechanisms. Nicotine \& Tobacco Research, 12, 768-775. doi:10.1093/ntr/ntq086

Rimé, B., Kanyangara, P., Yzerbyt, V., \& Paez, D. (2011). The impact of Gacaca tribunals in Rwanda: Psychosocial effects of participation in a truth and reconciliation process after a genocide. European Journal of Social Psychology, 41, 695-706. doi: 10.1002/ejsp.822

Rouhana, N. (2004). Group identity and power asymmetry in reconciliation processes: The Israeli-Palestinian case. Peace and Conflict: Journal of Peace Psychology, 10, 33-52. doi: 10.1207/s15327949pac1001_3

Shnabel, N., Halabi, S., \& Noor, M. (2013). Overcoming competitive victimhood and facilitating forgiveness through re-categorization into a common victim or perpetrator identity. Journal of Experimental Social Psychology, 49, 867-877. doi: 10.1016/j.jesp.2013.04.007

Shnabel, N., \& Noor, M. (2012). Competitive victimhood among Jewish and Palestinian Israelis reflects differential threats to their identities. In K. Jonas \& T. Morton (Eds.), 
Restoring civil societies: The psychology of intervention and engagement following crisis (pp. 192-207). Chichester, UK: Wiley-Blackwell.

Siman Tov-Nachlieli, I., \& Shnabel, N. (2014). Feeling both victim and perpetrator: Investigating duality within the needs-based model. Personality and Social Psychology Bulletin, 40, 301-314. doi: 10.1177/0146167213510746

Staub, E. (2006). Reconciliation after genocide, mass killing, or intractable conflict: Understanding the roots of violence, psychological recovery, and steps toward a general theory. Political Psychology, 27, 867-894. doi:10.1111/j.14679221.2006.00541.x

Staub, E., Pearlman, L., Gubin, A., \& Hagengimana, A. (2005). Healing, reconciliation, forgiving and the prevention of violence after genocide or mass killing: An intervention and its experimental evaluation in Rwanda. Journal of Social and Clinical Psychology, 24, 297-335. doi: 10.1521/jscp.24.3.297.65617

Tam, T., Hewstone, M., Cairns, E., Tausch, N., Maio, G., \& Kenworthy, J. (2007). The impact of intergroup emotions on forgiveness in Northern Ireland. Group Processes \& Intergroup Relations, 10, 119-136. doi: 10.1177/1368430207071345

Tutu, D. (1999). No future without forgiveness: A personal overview of South Africa's Truth and Reconciliation Commission. London: Random House.

Van Tongeren, D. R., Burnette, J. L., O’Boyle, E., Worthington, E. L., \& Forsyth, D. R. (2014). A meta-analysis of intergroup forgiveness. The Journal of Positive Psychology, 9, 81-95. doi:10.1080/17439760.2013.844268

Vollhardt, J. R. (2009). The role of victim beliefs in the Israeli-Palestinian conflict: Risk or potential for peace? Peace and Conflict: Journal of Peace Psychology, 15, 135-159. doi: 10.1080/10781910802544373

Vollhardt, J.R. (2012). Collective victimisation. In L. Tropp (Ed.), The Oxford handbook of intergroup conflict (pp. 136-157). Oxford: Oxford University Press. 
Vollhardt, J. R. (2013). “Crime against humanity” or "Crime against Jews"?

Acknowledgment in construals of the Holocaust and its importance for intergroup relations. Journal of Social Issues, 69, 144-161. doi:10.1111/josi.12008

Vollhardt, J.R. \& Bilali, R. (2014). The role of inclusive and exclusive victim consciousness in predicting intergroup attitudes: Findings from Rwanda, Burundi and DRC. Political Psychology, in press. doi: 101111/pops.1274

Wohl, M. J. A., \& Branscombe, N. (2005). Forgiveness and collective guilt assignment to historical perpetrator groups depend on level of social category inclusiveness. Journal of Personality and Social Psychology, 88, 288-303. doi:10.1037/0022-3514.88.2.288

Wohl, M. J. A., Branscombe, N. R., \& Klar, Y. (2006). Collective guilt: Emotional reactions when one's group has done wrong or been wronged. European Review of Social Psychology, 17, 1-37. doi:10.1080/10463280600574815 
Table 1. Correlations, Means and Standard Deviation for the total sample $(N=400)$

\begin{tabular}{|c|c|c|c|c|c|c|c|c|c|c|}
\hline Variables & 1 & 2 & 3 & 4 & 5 & 6 & 7 & 8 & 9 & 10 \\
\hline 1. Peace vision & - & $.64 * *$ & $.62 * *$ & $.61 * *$ & .06 & $.27 * *$ & $-.35 * *$ & $-.55 * *$ & $.16^{* *}$ & -.04 \\
\hline 2. Forgiveness & & - & $.57 * *$ & $.56^{* *}$ & .03 & $.27 * *$ &.$-34 * *$ & $-.52 * *$ & $.16^{* *}$ & $-.11^{*}$ \\
\hline 3. Trust & & & - & $.52 * *$ & -.02 & $.12 *$ & $-.28 * *$ & $-.57 * *$ & $.12 *$ & .02 \\
\hline 4. Inclusive victim perceptions & & & & - & -.04 & $.15^{* *}$ & $-.25^{* *}$ & $-.45 * *$ & $.20 * *$ & .05 \\
\hline 5. Income & & & & & - & $.10^{*}$ & -.02 & -.01 & $.23 * *$ & -.05 \\
\hline 6. Age & & & & & & - & $-.25 * *$ & $-.25 * *$ & $.09+$ & -.16 \\
\hline 7. Religiosity & & & & & & & - & $.39 * *$ & -.02 & .07 \\
\hline 8. Political orientation & & & & & & & & - & $-.14 * *$ & .05 \\
\hline 9. Education & & & & & & & & & - & -.03 \\
\hline 10. Gender & & & & & & & & & & - \\
\hline$M$ & 4.50 & 3.38 & 2.82 & 4.77 & 3.41 & - & 1.72 & 4.60 & - & - \\
\hline$S D$ & 1.58 & 1.72 & 1.26 & 1.68 & 2.32 & - & 1.17 & 1.60 & - & - \\
\hline
\end{tabular}

$+p<.1, * p<.05, * * p<.01$. Gender was coded such that $1=$ male, $2=$ female.

Means and standard deviations appear for variables measured using continuous scales;

frequencies of variables measured using categorical scales (i.e., age, level of education and gender) are reported in the Respondents section. 
Table 2. The Direct and Indirect Effects of Trust, Inclusive Victim Perceptions and Forgiveness on Peace Vision Endorsement among Israeli Jews

\begin{tabular}{lrrrr}
\hline & $B$ & $S E$ & $t$ & $p$ \\
\hline Criterion Variable: Forgiveness & & & & \\
Trust & .387 & .065 & 5.987 & .001 \\
Inclusive Victim Perceptions & .318 & .045 & 7.010 & .001 \\
Political Orientation & -.159 & .051 & -3.117 & .002 \\
Religiosity & -.132 & .059 & -2.216 & .027 \\
Income & .017 & .028 & .601 & .548 \\
Education & .032 & .056 & .566 & .572 \\
Gender & -.345 & .127 & -2.717 & .007 \\
Age & .104 & .039 & 2.666 & .008 \\
\hline
\end{tabular}

Criterion Variable: Peace Vision Endorsement

$\begin{array}{lrrrr}\text { Forgiveness } & .215 & .042 & 5.137 & .001 \\ \text { Trust } & .314 & .056 & 5.619 & .001 \\ \text { Inclusive Victim Perceptions } & .251 & .040 & 6.286 & .001 \\ \text { Political Orientation } & -.118 & .043 & -2.758 & .006 \\ \text { Religiosity } & -.090 & .050 & -1.813 & .071 \\ \text { Income } & .038 & .023 & 1.653 & .099 \\ \text { Education } & .002 & .046 & .047 & .963 \\ \text { Gender } & -.015 & .106 & -.143 & .887 \\ \text { Age } & .077 & .033 & 2.367 & .018\end{array}$

Note. $N=400$. Political Orientation was coded using a 7-point scale such that $1=$ Leftist and $7=$ Rightist, Gender was coded such that $1=$ male and $2=$ female. 


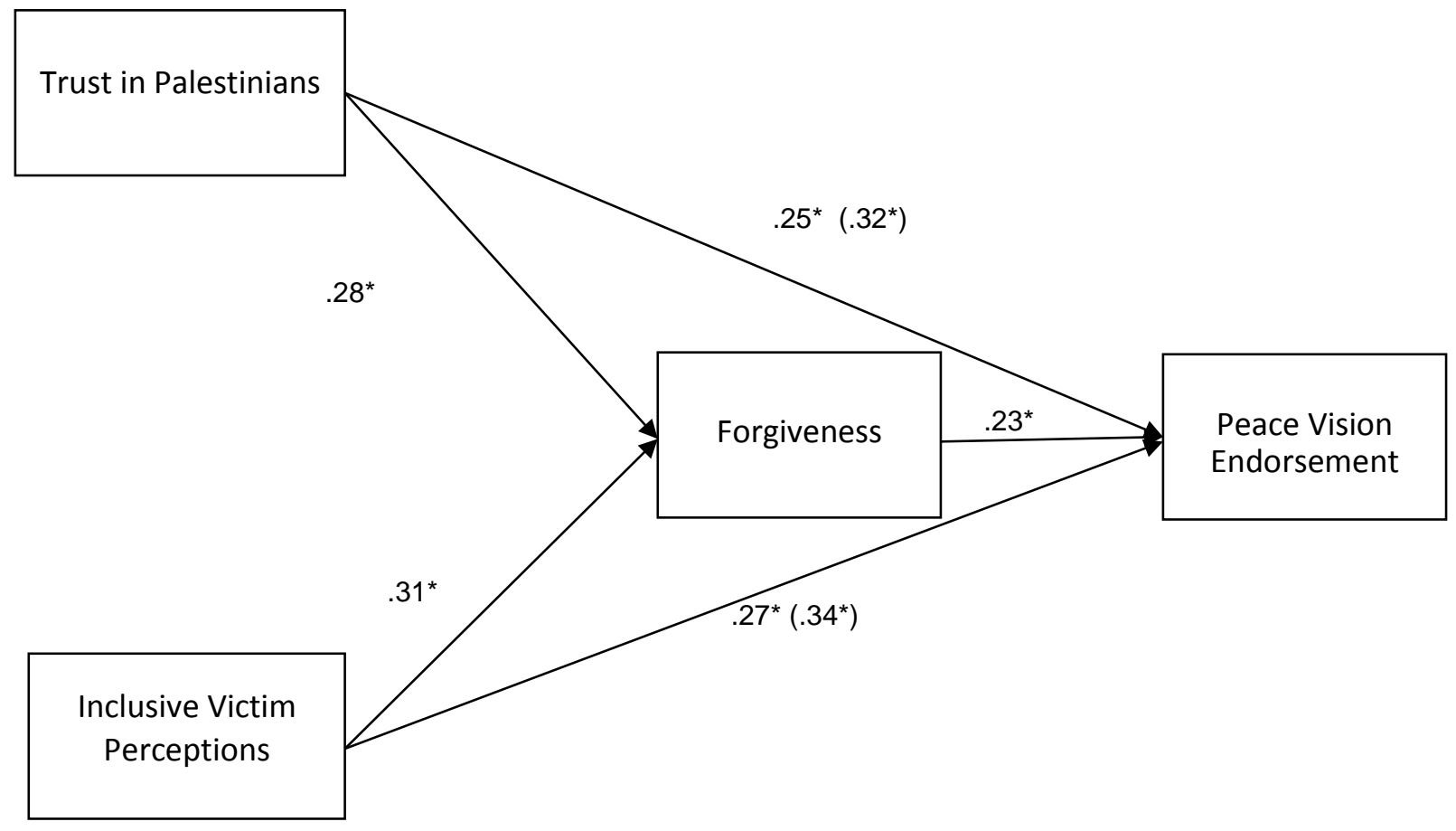

Figure 1: the proposed associations between socio-emotional factors leading to peace vision endorsement. Standardized regression coefficients (betas) are presented. Participants' gender, age, education, income, religiosity, and political orientation are controlled for. For the paths between trust and peace vision endorsement, and between inclusive victim perceptions and peace vision endorsement the coefficients shown outside vs. inside the parentheses represent the direct and total effects, respectively. Coefficients with one asterisk indicate beta weights' significance level of $p<.001$. The indirect effects of trust and inclusive victim perceptions on peace vision endorsement through forgiveness were significant (confidence intervals are reported in the Results section). 